\title{
The Assessment of The Effect of Proximity of Septic Tanks on The Levels of Selected Heavy Metals in Borehole Water from Ongata Rongai, Kajiado County, Kenya
}

\author{
N. K. Ochiba, D. A. Abong'o, J.O. Onyatta \\ Department of Chemistry, University of Nairobi, P.O Box 30197-00100, Nairobi, Kenya \\ *Corresponding author, email : nancy.khayongo@gmail.com
}

\begin{abstract}
Article Info

Volume 8, Issue 4

Page Number : 64-76

Publication Issue :

July-August-2021

\section{Article History}

Accepted : 06 July 2021

Published: 13 July2021

The study was carried out to evaluate the levels of heavy metals in groundwater samples from ten selected boreholes in Ongata Rongai town, Kajiado County. The selected heavy metals analyzed were: $\mathrm{Zn}, \mathrm{Pb}, \mathrm{Hg}, \mathrm{Mn}, \mathrm{Cd}$ and $\mathrm{Cr}$ in the dry and wet seasons. The effect of the proximity of septic tanks distance to borehole was also determined. The statistical analyses of the data using a 2-way ANOVA showed 95\% confidence level $(\mathrm{p}<0.05)$ interdependence of the distance from the boreholes and contaminant levels. The study showed that heavy metals were below the maximum recommended level and the guideline values of World Health Organization and Kenya Bureau of Standards. The analyses of the selected heavy metals, by Flame Atomic Absorption Spectroscopy, revealed that the detected levels of Mn $(0.03 \pm 0.01-0.26 \pm 0.01$ $\mathrm{mgl}^{-1}$ ) were higher than those recommended by WHO and KEBS of $0.01 \mathrm{mgl}^{-1}$, while $\mathrm{Zn}\left(0.11 \pm 0.02-0.73 \pm 0.01 \mathrm{mgl}^{-1}\right)$ are within acceptable levels of WHO $\left(3.0 \mathrm{mgl}^{-1}\right)$ and KEBS $\left(5.0 \mathrm{mgl}^{-1}\right)$. There was no strong correlation between the distance of borehole from septic tanks and heavy metal levels in water samples. The low detected values should not be overlooked as the heavy metals are capable of bio-accumulating in body tissues.
\end{abstract}

Keywords: Heavy metals, Septic tank distance, borehole water, assessment, Levels

\section{INTRODUCTION}

The study by [1] described heavy metals as a metal element that has a comparably high density and are hazardous at little concentrations. However, [2] were more specific and described heavy metals as "Groups or metals or metalloids with an atomic density larger than $4 \mathrm{~g} / \mathrm{cm}^{3}$ or is 5 times denser than water". [2]
Emphasized that the "Density of heavy metal is of minimal concern but the emphasis should be placed on their chemical properties instead" [3].

The health effects of heavy metals and metalloid contamination in the surrounding environment is a growing concern globally as reported by [4] they attributed this is due to the persistence of heavy metals. Mercury, Lead, Cadmium, and Arsenic have 
been known to cause detrimental health problems [5]. These metals naturally occur in the surrounding but are also released into the environment due to anthropogenic activities that largely contribute to their existence in the environment. [4] list some of the anthropogenic activities that lead to the release of heavy metals into the environment as mining, industrial waste disposal, transport sector, agricultural activities, and the domestic effluent disposal systems. The study carried out by [6] also added that both natural and anthropogenic process lead emission of heavy metals to the environment. The metal ions bio accumulate in biota and are removed by desorption into the environment, leading to their toxic nature among other abundant sources [7] and as such, there is need to assess the concentrations of heavy metal regularly in the environment. Heavy metals occur in our environment as particulates, dissolved and colloidal phases [8].

Therefore, it is important to assess the chemical characteristics of water and determine the concentrations of heavy metals. They are currently the most persistent water impurities with known detrimental effects on human health. These heavy metals are transported in water as an outcome of improper disposal of industrial waste, electronic waste, municipal wastewater, landfill leachates, mining activities and natural geochemical weathering of rocks [4]. They also added that volatile and particulate metal compounds are carried from one place to another by the wind. These heavy metals include; Lead, Zinc, Mercury, Manganese, Chromium, and Cadmium. However, according to [9], the concentration of these metals has greatly increased due to human activities.

Septic tanks as a source of groundwater contamination

Human excreta contains traces of heavy metals, in feces and in urine, which have a characteristic of accumulation in the soil, sediment, and would eventually reach the groundwater, from within 3 days to months and therefore the recommended distances of septic tanks from boreholes is 50 feet or approximately $15 \mathrm{~m}$ according to [10] as shown in Figure 1. [11] acknowledge the risk posed by cesspits to underground water by highlighting that the largest risks of human exposure from contents discharged into a soak pit or cesspit occur during emptying the pit contents, or through contamination of groundwater when used as a source of drinking water in proximity of the effluent leaving a soak pit, and when a pit is overflowing due to system malfunctioning.

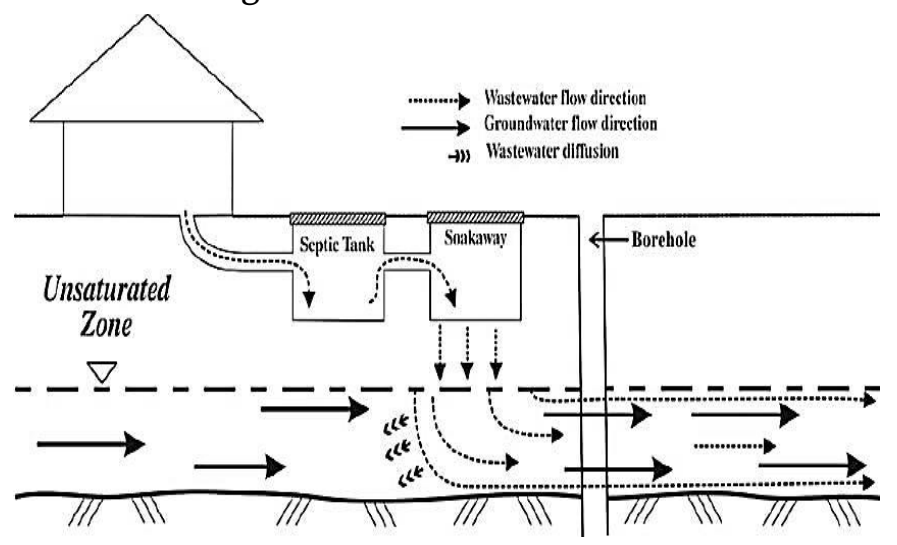

Figure 1 : Septic tank soakway system, waste water flowing into a borehole [12]

The government regulations for sizing and design of septic tank requires that for a 20 block apartment with 2 occupants per unit, the capacity should be $2400 \mathrm{~L}$ per day which would mean about $3 \mathrm{~m}$ deep by $1.5 \mathrm{~m}$ which make it easier to maintain when inspecting to check and repair cracks in the impermeable concrete lining or wall, which would cause sludge to leak, or even the efficiency of sludge suction pumps due to high head or depth [13]. Improper use of the septic tanks by disposing of hazardous wastes containing heavy metals or highly acidic waste that lowers the $\mathrm{pH}$, making the free ions mobile in solution, combined with poor design and poor maintenance makes the use of septic tanks risky to the groundwater [13]. 


\section{Materials and Methodology}

\section{1) The Study Area}

The study area, Ongata Rongai, (Figure 2), sits on an area of $16.5 \mathrm{~km}^{2}$ and has 60,184 households with a total of 178,795 people [14]. It is found at $50 \mathrm{~km}$ from Kajiado County headquarters and $20 \mathrm{~km}$ from Nairobi County Central Business District (CBD) along the Langata-Magadi road. It lies approximately at latitude $\left(0^{\circ} 53^{\prime} 60^{\prime \prime} \mathrm{S}\right)$ and longitude (36 25' 60" E) (Table 1).

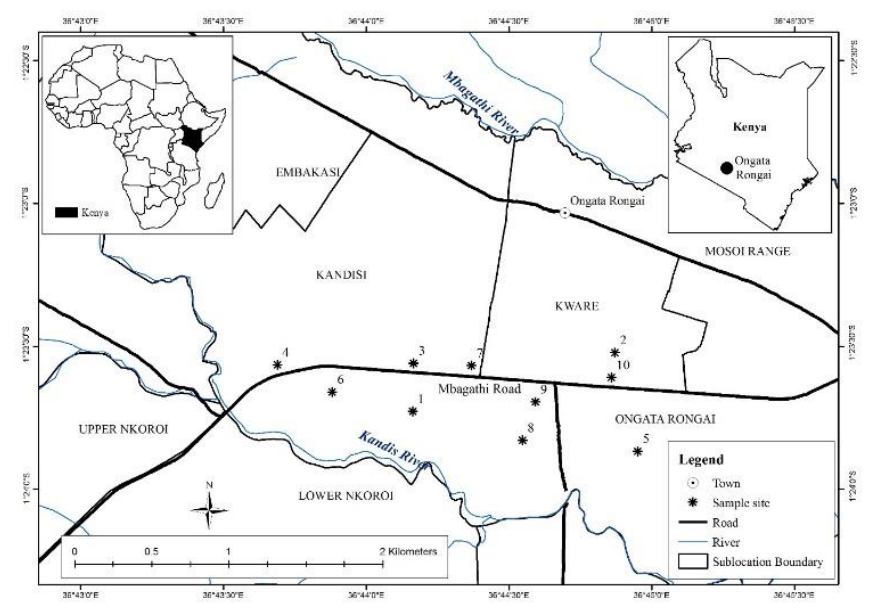

Figure 2: Map showing selected borehole sampling sites in Ongata Rongai

The Sampling Site selection

The sampling sites (Table 1) and coordinates for the selected boreholes, following a cadastral map of Ongata Rongai town, along Magadi Road, based on the socio-economic classification and population density, was recorded by a hand-held Global Positioning System (GPS) receiver (Map 410 Magellan). A total of 10 boreholes in the study area (Figure 2) located next to the septic tanks sewage disposal systems $(\leq 200 \mathrm{~m}$ ) were selected for water sampling in dry (March) and wet (May) seasons in 2019. The baseline data (Table 2) from [15] provided useful information on depth, water rest levels and yield at the time of drilling the boreholes before water sampling was done. The determination and recording of the distance between each borehole and the septic tanks was also done.

Table 1: Sampling sites GIS location and a description of the surrounding area

\begin{tabular}{|l|l|l|l|}
\hline $\begin{array}{l}\text { Site } \\
\text { No. }\end{array}$ & $\begin{array}{l}\text { Altitude } \\
(\mathrm{m})\end{array}$ & Coordinates & Description of sampling sites surroundings \\
\hline 1 & 1788 & $\begin{array}{l}01^{\circ} 23^{\prime} 42^{\prime \prime} \mathrm{S} \\
36^{0} 45^{\prime} 49^{\prime \prime} \mathrm{E}\end{array}$ & $\begin{array}{l}\text { Muslim mosque with borehole. The very densely populated area } \\
\text { near a slaughterhouse. Surrounded by flats. One Septic tank at } 30 \\
\text { m and an abandoned horticulture farm nearby. }\end{array}$ \\
\hline 2 & 1794 & $\begin{array}{l}01^{0} 23^{\prime} 45^{\prime \prime} \mathrm{S} \\
36^{0} 43^{\prime} 40^{\prime \prime} \mathrm{E}\end{array}$ & $\begin{array}{l}\text { New life mission. Borehole at the slope. Densely populated } \\
\text { shopping centre. Septic tanks at about 33 m }\end{array}$ \\
\hline 3 & 1793 & $\begin{array}{l}01^{0} 28^{\prime} 45^{\prime \prime} \mathrm{S} \\
36^{0} 45^{\prime} 49^{\prime \prime} \mathrm{E}\end{array}$ & $\begin{array}{l}\text { Near the shopping centre. Heavy water abstraction for sale. } \\
\text { Medium population }\end{array}$ \\
\hline 4 & 1780 & $\begin{array}{l}01^{0} 25^{\prime} 40^{\prime \prime} \mathrm{S} \\
36^{0} 23^{\prime} 36^{\prime \prime} \mathrm{E}\end{array}$ & $\begin{array}{l}\text { Mbathi's house. The borehole has been in use for 15 years. } \\
\text { Homestead at a higher side of property's slope, Septic tank at about } \\
31 \mathrm{~m}\end{array}$ \\
\hline 5 & 1788 & $\begin{array}{l}02^{\circ} 00^{\prime} 06^{\prime \prime} \mathrm{S} \\
37^{0} 26^{\prime} 18^{\prime \prime} \mathrm{E}\end{array}$ & $\begin{array}{l}\text { Borehole along the chief's camp. Densely populated, septic tanks at } \\
\text { about 15 m }\end{array}$ \\
\hline 6 & 1781 & $\begin{array}{l}02^{\circ} 03^{\prime} 00^{\prime \prime} \mathrm{S} \\
37^{0} 23^{\prime} 00^{\prime \prime} \mathrm{E}\end{array}$ & $\begin{array}{l}\text { Three flats with fifty houses each. The borehole is within the } \\
\text { compound of the flat. Septic tanks at about 120 m }\end{array}$ \\
\hline
\end{tabular}




\begin{tabular}{|l|l|l|l|}
7 & 1791 & $\begin{array}{l}01^{0} 38^{\prime} 56^{\prime \prime} \mathrm{S} \\
36^{0} 44^{\prime} 34^{\prime \prime} \mathrm{E}\end{array}$ & $\begin{array}{l}\text { Muslim mosque and a slaughterhouse nearby in a densely } \\
\text { populated area. River 70 m at the bottom of the slope. Mean septic } \\
\text { tanks at about 16m }\end{array}$ \\
\hline 8 & 1790 & $\begin{array}{l}01^{0} 28^{\prime} 24^{\prime \prime} \mathrm{S} \\
36^{0} 31^{\prime} 23^{\prime \prime} \mathrm{E}\end{array}$ & $\begin{array}{l}\text { Gather's house, with borehole. In a low-density area with bigger } \\
\text { plot size homesteads. On flat ground, Septic tank at about 33m }\end{array}$ \\
\hline 9 & 1781 & $\begin{array}{l}02^{\circ} 08^{\prime} 21^{\prime \prime} \mathrm{S} \\
37^{0} 00^{\prime} 06^{\prime \prime} \mathrm{E}\end{array}$ & $\begin{array}{l}\text { Albanus apartments, Borehole next to a flat of } 60 \text { houses. One big } \\
\text { capacity Septic tank at about 32 m }\end{array}$ \\
\hline 10 & 1776 & $\begin{array}{l}01^{0} 18^{\prime} 30^{\prime \prime} \mathrm{E} \\
36^{0} 41^{\prime} 22^{\prime \prime} \mathrm{S}\end{array}$ & $\begin{array}{l}\text { Ndungu Ole kapara borehole in a remote area. Septic tanks at } \\
\text { about 146 m }\end{array}$ \\
\hline
\end{tabular}

coded by single digits as borehole site numbers as

\section{Baseline information on the borehole water sampling} sites

The baseline information that guided in selecting the study sites is given in Table 2 . The borehole serial numbers were from the previous study [15] which was retrieved and recorded from national datum of registered boreholes, from the ministry of water and irrigation in the year 2012. These serial numbers were described in Table 2 and for convenience of data handling. The water rest level was the measured height of how high the groundwater rises and rests in the borehole, based on groundwater hydrostatic pressure mainly used to determine the size and depth of pump installations. This data was also retrieved from the ministry of water and irrigation.

Table 2. Baseline data on boreholes water and their distance from the septic tanks

\begin{tabular}{|c|c|c|c|c|c|c|c|c|c|c|}
\hline $\begin{array}{l}\text { Borehole serial } \\
\text { number }\end{array}$ & 6231 & 9262 & 9262 & 13435 & 10663 & 13850 & 13732 & 19870 & 19653 & 20944 \\
\hline Borehole Site & 1 & 2 & 3 & 4 & 5 & 6 & 7 & 8 & 9 & 10 \\
\hline Water rest level $(\mathrm{m})$ & 30 & 20.3 & 48 & 51 & 27 & 67 & 43 & 116 & 23 & 50 \\
\hline Borehole depth (m) & 210 & 80 & 178 & 234 & 94 & 296 & 162 & 286 & 130 & 160 \\
\hline Yield $\left(\mathrm{m}^{3} \mathrm{hr}^{-1}\right)$ & 6 & 12 & 13 & 10.6 & 12.6 & 9.8 & 12 & 10.3 & 10 & 9 \\
\hline Septic tank number & \multicolumn{10}{|c|}{ The distance of the septic tank from the borehole's sampling sites (m) } \\
\hline A & 30 & 25 & 24 & 6 & 9 & 30 & 15 & 15 & 15 & 60 \\
\hline $\mathrm{B}$ & 40 & 20 & 50 & 7 & 12 & 110 & 15 & 30 & 15 & 120 \\
\hline $\mathrm{C}$ & 50 & 20 & 70 & 9 & 15 & 110 & 15 & 30 & 30 & 150 \\
\hline $\mathrm{D}$ & 50 & 40 & 70 & 25 & 15 & 150 & 15 & 40 & 40 & 190 \\
\hline $\mathrm{E}$ & 140 & 60 & 90 & 110 & 30 & 200 & 20 & 50 & 60 & 210 \\
\hline Mean distance $(\mathrm{m})$ & 63 & 33 & 60.8 & 31.4 & 16.2 & 120 & 16 & 33 & 32 & 146 \\
\hline
\end{tabular}


Baseline data on boreholes water and their distance from the septic tanks [15]

The borehole depth, in meters, was the actual drilled or dug depth, from top to bottom of the borehole. The data was retrieved from the ministry of water and irrigation. The yield, in cubic meters per hour, was the quantity of water that could be abstracted from the borehole as a function of time, until the well ran dry, before the next recharge. This was done using a standard, calibrated submersible pump after drilling. The yield was dynamic depending on the number of boreholes pumped within the same aquifer and also affects the water rest level. The data was retrieved from the ministry of water and irrigation. The letters A, B, C, D, and E represented the five nearest septic tanks within minimum radial distances from the borehole sites under investigation. The mean borehole-septic tanks spatial distances in Table 2 were used

\section{Chemicals and reagents}

Stock solutions of each of 1000ppm of zinc, lead, cadmium, chromium, and manganese standards were prepared from heating metal reagents (99.9\%) while mercury was obtained from $\mathrm{HgCl}_{2}$, salt. Analytical quality chemicals and reagents were used; they were obtained from BDH laboratory reagents, (Ltd Poole England). Cleaning of glassware and plastic apparatus ware was done thrice with deionized water and then immersed in $20 \%$ nitric acid overnight. The apparatus were then rinsed thrice with deionized water and dried in Mermert oven.

\section{Instrumental and apparatus}

A hand-held Global Positioning System (GPS) receiver (Map 410 Magellan) was used to obtain the coordinates of the sampling sites. Analytical balance (Sartorius 1213 MP model), water deionizer (Ionizer Mk 8), Mermert Oven, Flame Atomic Absorption Spectrophotometer (Perkin Elmer 2380) and sampling plastic containers were used. The apparatus used include; sampling $2.0 \mathrm{~L}$ plastic containers, $50 \mathrm{ml}, 250$ $\mathrm{ml}$ beakers, measuring cylinder $10 \mathrm{ml}$ and $100 \mathrm{ml}$, volumetric flask $50 \mathrm{ml}, 100 \mathrm{ml}$, and $1000 \mathrm{ml}$ and watch glass.

\section{Sample collection}

Surveys and familiarization with sampling sites were done (Figure 2) in January 2019, by visiting various borehole owners to seek their consent. Sampling was done in March and May, 2019 representing the dry and wet seasons respectively. Samples were collected in May and March accounted for the seasonal variations; May is the wet while March being the dry season. Water samples were obtained from the selected ten borehole sites (Figure 2) a representative of the Ongata Rongai area for the dry and wet seasons. Water sampling was done using the [16] which covers the standard methods for the examination of waters and wastewaters as well as water quality sampling by opening the tap at each sampling site, draining out the water for 1minute. Samples from ten boreholes sites in Ongata Rongai area were taken in pre-cleaned $2.0 \mathrm{~L}$ plastic containers for physico-chemical parameters and heavy metal analysis, each sample was labeled and kept in polyurethane cool boxes then transported to the Cropnut Laboratory, Nairobi, for analysis. On-site data and observation and the description of surroundings of the sampling sites were documented (Table 1) that include the exact water resource location, weather conditions at the time of sampling. It was observed that galvanized zinc pipes were used for water piping. Laboratory tests were done according to [16]. Care was taken to ascertain that the samples were truly representing the existing conditions in the study area.

Acid digestion for the analysis of heavy metals

The water samples were obtained from ten sites (Table 1) for the selected ten boreholes were acid digested as recommended by the standard procedure [17], to each $100 \mathrm{ml}$ triplicate water sample in a precleaned $250 \mathrm{ml}$ beaker, $25 \mathrm{ml}$ of $10 \%$ hydrochloric (2.5 $\mathrm{ml}$ concentrated hydrochloric acid $+22.5 \mathrm{ml}$ 
distilled deionized water) was added to the beaker and heated on a hot plate. The solution was boiled until 10-15 ml was left. $10 \mathrm{ml}$ of perchloric acid was added and the solution was heated until perchloric fumes evolved (observed). The remaining sample was put in a $100 \mathrm{ml}$ volumetric flask and topped to the mark. The solution was then shaken well and transferred into a clean sampling bottle awaiting analysis by AAS. The samples were prepared in triplicates from every site.

Preparation of heavy metal standard stock solutions and calibration curves

The following standard stock solutions were prepared for the heavy metal analysis. $1000 \mathrm{mgl}^{-1}$ of zinc (Zn), lead $(\mathrm{Pb})$ and Cadmium $(\mathrm{Cd})$ stack solutions were prepared by heating $1.0 \mathrm{~g}$ of the metals $(99.9 \%)$ and dissolving it in $30 \mathrm{ml}(1: 1 \mathrm{v} / \mathrm{v})$ of water: nitric acid solution then transferring the solution to $1000 \mathrm{ml}$ volumetric flask. $1000 \mathrm{mgl}^{-1}$ of mercury ( $\mathrm{Hg}$ ) standard stock solution was prepared by dissolving $1.354 \mathrm{~g}$ of analytical grade salt of $\mathrm{HgCl}_{2}$ (99.9\%). These solutions were dissolved in distilled deionized water and diluting to the mark while $1000 \mathrm{mgl}^{-1}$ of manganese $(\mathrm{Mn})$ and Chromium (Cr) of ion standard stock solutions were prepared by heating $1.0 \mathrm{~g}$ of the metals (99.9\%) and dissolved in $20 \mathrm{ml}$ of aqua regia and diluted to 1 litre. The calibration standard curves for each metal ion was prepared by diluting $1000 \mathrm{mgl}^{-1}$ stock solution to the required range.

\section{Quality control assurance}

Quality assurance control was ascertained by analysis of blank solutions. The quality control was carried out as recommended by [18] analysis of laboratory reagent and fortified blanks, as well as samples as an ongoing measurement of performance. Rinsed blanks and calibration of six standard solutions of all monitored analytes were prepared at parts per million (ppm) or parts per billion (ppb) concentration ranges for the various analytes.

\section{Analysis of the heavy metals with Atomic Absorption Spectrometry (AAS)}

Samples were analyzed by direct absorption, except for mercury which was done by cold vapor generation in a special accessory. The samples were analyzed in triplicates to minimize errors. The Flame Atomic Absorption Spectroscopy (FAAS) was warmed up and the recommended wavelengths and flame/gas types set for the various heavy metals analysis as shown in Table 3.

Table 3 Atomic Absorption Spectrometry wavelengths and flame gas used for heavy metal analysis

\begin{tabular}{|l|l|l|}
\hline Element & $\begin{array}{l}\text { Wavelength } \\
(\mathrm{nm})\end{array}$ & Flame/ gases \\
\hline Zinc & 213.9 & air/acetylene \\
\hline Lead & $217.0 / 283.3$ & air/acetylene \\
\hline Mercury & 253.7 & $\begin{array}{l}\text { Cold vapour } \\
\text { generation }\end{array}$ \\
\hline Manganese & 279.5 & air/acetylene \\
\hline Cadmium & 228.8 & air/acetylene \\
\hline Chromium & 357.9 & air/acetylene \\
\hline
\end{tabular}

The heavy metals: Zinc ( $\mathrm{Zn})$, Lead (Pb), Mercury (Hg), Manganese (Mn), Cadmium (Cd), and Chromium (Cr), and were determined by Perkin Elmer 2380 Flame Atomic Absorption Spectrophotometer. Procedures by [18] were followed during preparation of samples to be analyzed. The operating manual was used to give guidance setting up and optimization of the instrument and air- acetylene mixture was used as source of flame. However, for the determination of $\mathrm{Hg}$, hydride generation method was used. The samples were all analyzes in triplicate and the wavelengths for the determination of each metal are shown in Table 3.

\section{RESULTS AND DISCUSSION}

Table 4 shows the levels of the heavy metal ions in water samples in dry and wet seasons 
Table 4 : Concentrations of selected heavy metals in 10 samples sites in dry and wet seasons

\begin{tabular}{|c|c|c|c|c|c|c|}
\hline \multicolumn{7}{|c|}{ Heavy metal level } \\
\hline \multicolumn{7}{|c|}{ Dry Season } \\
\hline Site & $\begin{array}{l}\text { Zinc } \\
\left(\mathrm{mgl}^{-1}\right)\end{array}$ & $\begin{array}{l}\text { Lead } \\
\left({ }^{\mathrm{mgl}-1}\right)\end{array}$ & $\begin{array}{l}\text { Mercury } \\
\left(\mathrm{mgl}^{-1}\right)\end{array}$ & $\begin{array}{l}\text { Manganese } \\
\left(\mathrm{mgl}^{-1}\right)\end{array}$ & $\begin{array}{l}\text { Cadmium } \\
\left(\mathrm{mgl}^{-1}\right)\end{array}$ & $\begin{array}{l}\text { Chromium } \\
\left(\mathrm{mgl}^{-1}\right)\end{array}$ \\
\hline 1 & $0.16 \pm 0.01$ & $0.22 \pm 0.02$ & $0.0017 \pm 0.0002$ & $0.12 \pm 0.00$ & BDL & BDL \\
\hline 2 & $0.73 \pm 0.01$ & $0.33 \pm 0.01$ & $0.0017 \pm 0.0001$ & $0.09 \pm 0.01$ & BDL & BDL \\
\hline 3 & $0.16 \pm 0.02$ & $0.22 \pm 0.01$ & $0.0018 \pm 0.0003$ & $0.22 \pm 0.00$ & BDL & BDL \\
\hline 4 & $0.32 \pm 0.00$ & $0.30 \pm 0.02$ & $0.0019 \pm 0.0001$ & $0.19 \pm 0.01$ & BDL & $\mathrm{BDL}$ \\
\hline 5 & $0.51 \pm 0.01$ & $0.42 \pm 0.011$ & $0.0017 \pm 0.0001$ & $0.26 \pm 0.001$ & BDL & BDL \\
\hline 6 & $0.21 \pm 0.01$ & $0.24 \pm 0.01$ & $0.0016 \pm 0.0001$ & $0.18 \pm 0.01$ & BDL & BDL \\
\hline 7 & $0.11 \pm 0.02$ & $0.22 \pm 0.00$ & $0.0013 \pm 0.0002$ & $0.05 \pm 0.01$ & BDL & BDL \\
\hline 8 & $0.68 \pm 0.01$ & $0.24 \pm 0.01$ & $0.0010 \pm 0.0001$ & $0.13 \pm 0.00$ & BDL & BDL \\
\hline 9 & $0.14 \pm 0.01$ & $0.25 \pm 0.02$ & $0.0017 \pm 0.0001$ & $0.07 \pm 0.01$ & BDL & BDL \\
\hline 10 & $0.12 \pm 0.00$ & $0.23 \pm 0.02$ & $0.0002 \pm 0.0001$ & $0.03 \pm 0.01$ & BDL & BDL \\
\hline \multicolumn{7}{|c|}{ Wet season } \\
\hline 1 & $0.03 \pm 0.01$ & $0.21 \pm 0.01$ & $0.0017 \pm 0.0002$ & $0.17 \pm 0.01$ & BDL & BDL \\
\hline 2 & BDL & $0.25 \pm 0.01$ & $0.0016 \pm 0.0002$ & $0.11 \pm 0.01$ & BDL & BDL \\
\hline 3 & $0.18 \pm 0.01$ & $0.27 \pm 0.00$ & $0.0018 \pm 0.0001$ & $0.20 \pm 0.00$ & $\mathrm{BDL}$ & $\mathrm{BDL}$ \\
\hline 4 & BDL & $0.26 \pm 0.01$ & $0.0016 \pm 0.0001$ & $0.19 \pm 0.02$ & BDL & BDL \\
\hline 5 & $\mathrm{BDL}$ & $0.29 \pm 0.01$ & $0.0010 \pm 0.0002$ & $0.26 \pm 0.001$ & $\mathrm{BDL}$ & BDL \\
\hline 6 & BDL & $0.25 \pm 0.01$ & $0.0006 \pm 0.0002$ & $0.18 \pm 0.01$ & BDL & BDL \\
\hline 7 & $\mathrm{BDL}$ & $0.28 \pm 0.02$ & $0.0006 \pm 0.0001$ & $0.04 \pm 0.01$ & BDL & BDL \\
\hline 8 & BDL & $0.29 \pm 0.01$ & $0.0005 \pm 0.0002$ & $0.12 \pm 0.01$ & BDL & BDL \\
\hline 9 & $0.05 \pm 0.01$ & $0.26 \pm 0.01$ & $0.0019 \pm 0.0001$ & $0.07 \pm 0.02$ & BDL & BDL \\
\hline 10 & $0.03 \pm 0.01$ & $0.25 \pm 0.01$ & $0.0004 \pm 0.0001$ & $0.04 \pm 0.00$ & BDL & BDL \\
\hline LOD & 0.01 & 0.001 & 0.001 & 0.0001 & 0.001 & 0.005 \\
\hline \multicolumn{7}{|c|}{ Recommended values in drinking water } \\
\hline WHO & 3.0 & 0.01 & 0.006 & 0.01 & 0.003 & 0.05 \\
\hline KEBS & 5.0 & 0.05 & 0.001 & 0.01 & 0.005 & 0.05 \\
\hline
\end{tabular}


The recommended heavy metal values were obtained from WHO (2008) and KS EAS 153: 2014.

\section{Effects of septic tank distances on the levels of heavy metals}

Zinc levels were higher in dry season in Site $2\left(0.73 \pm 0.01 \mathrm{mgl}^{-1}\right)$ and lower in $7\left(0.11 \pm 0.02 \mathrm{mgl}^{-1}\right)$ (Table 4), with mean septic tanks distance of $33 \mathrm{~m}$ and $16 \mathrm{~m}$ from the borehole respectively (Table 2) while the highest and lowest levels in wet season were from Sites $3\left(0.18 \pm 0.01 \mathrm{mgl}^{-1}\right)$ and $1\left(0.03 \pm 0.01 \mathrm{mgl}^{-1}\right)$ with tanks mean distant at $60.8 \mathrm{~m}$ and $63 \mathrm{~m}$ respectively. In the wet season, Zinc was below detectable limit (BDL) of $0.01 \mathrm{mgl}^{-1}$ at Sites 2, 4, 5, 6, 7 and 8 that were at septic tank distances between 16m and 120m (Table 2). Figure 3 shows levels of zinc in water sample in dry and wet seasons

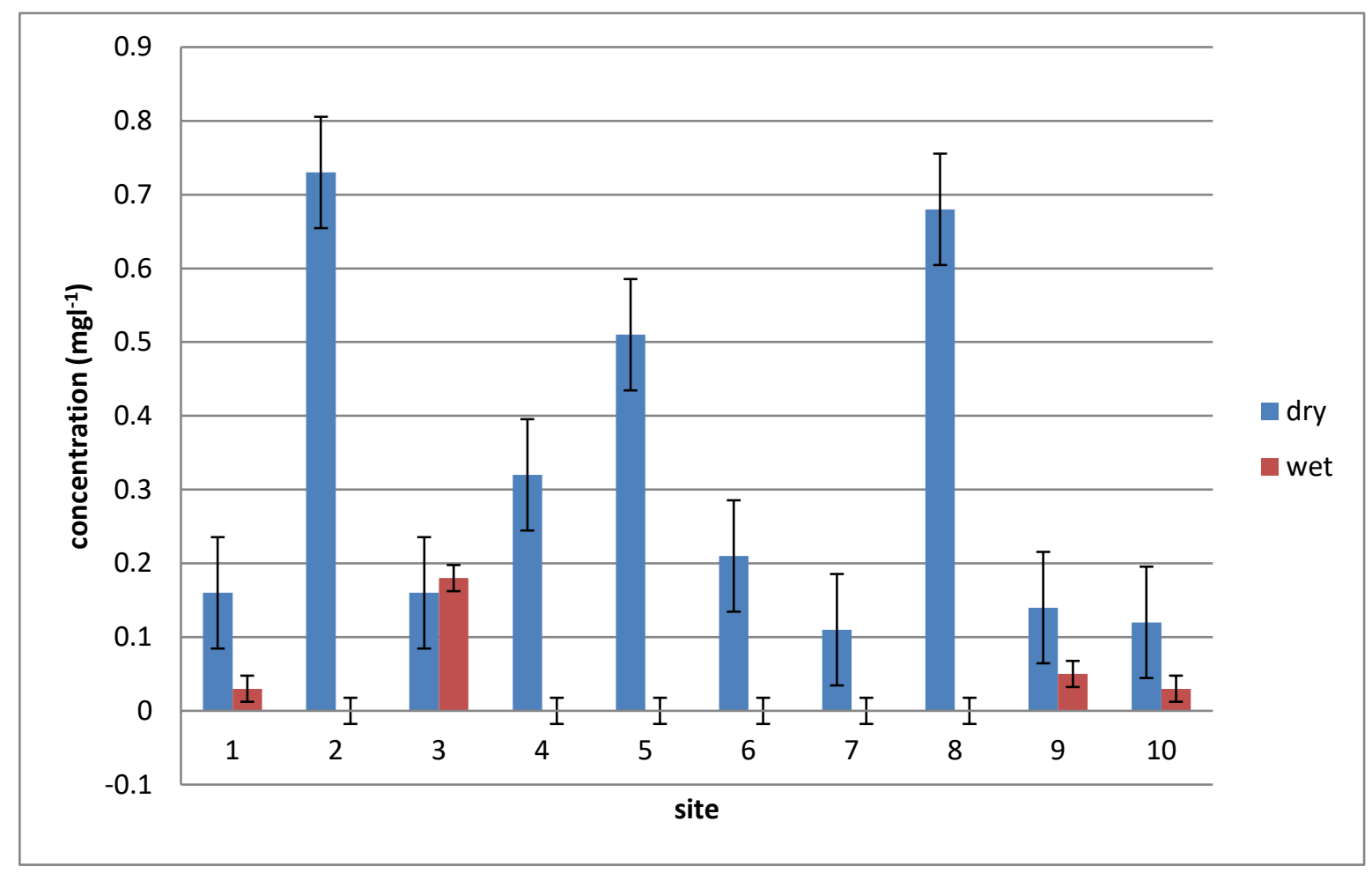

Figure 3: Zinc levels in ten borehole water samples

Zinc levels were high in dry season, probably due to the use of zinc galvanized pipe which cause corrosion therefore, causing significant zinc levels but lower in wet due to dilution process [7]. The level of zinc in the dry season was maximum in borehole Site 3 situated in area near the shopping centre that has heavy water abstraction for sale, medium population and septic tank at $33 \mathrm{~m}$ away. Zinc sources are from galvanized pipes used. Though zinc is naturally found in nature, there are also anthropogenic sources, for example the minimum distances from septic tanks and household products containing zinc oxide and zinc sulfide such as disposal of zinc chloride batteries [4]. Zinc oxide is used to make various products including make-up, prescription drugs and including other dietary sources present in human feces, could avail zinc into borehole water from the septic tanks. The selected boreholes sites were all constructed with a 4 inch (diameter) steel casing and 2 inch galvanized pipes immersed below the water rest level to the pump. The intimate contact, in $\mathrm{pH}<7$, likely anions present and dissolved oxygen $>1 \mathrm{ppm}$, makes the water corrosive (pourbiax relation), and likely to avail zinc ions in water [5]. [19] has listed fever, nausea, vomiting, stomach cramps, and diarrhea as some of the health complications caused by Zinc poisoning. The mean septic tank distance did not contribute much to the levels of $\mathrm{Zn}$ in the water samples 
The lead was observed in all water samples with the highest values in Site 5 in both dry and wet seasons at 0.42 $\pm 0.011 \mathrm{mgl}^{-1}$ and $0.27 \pm 0.00 \mathrm{mgl}^{-1}$ respectively (Table 4). The mean septic tanks distance from Site 5 was $16.2 \mathrm{~m}$, however, septic tanks A and B are within $9 \mathrm{~m}$ and $12 \mathrm{~m}$ respectively (Table 2). The lowest levels were recorded in site 1 at $63 \mathrm{~m}$ in both dry and wet seasons (Figure 4). Generally, the boreholes near the septic tanks (Table 2) had higher levels of $\mathrm{Pb}$ (Table 4). The levels were above recommended levels by WHO of $0.1 \mathrm{mgl}^{-1}$ but within KEBS levels in both dry and wet seasons at, 0.1 and $0.5 \mathrm{mgl}^{-1}$ respectively.

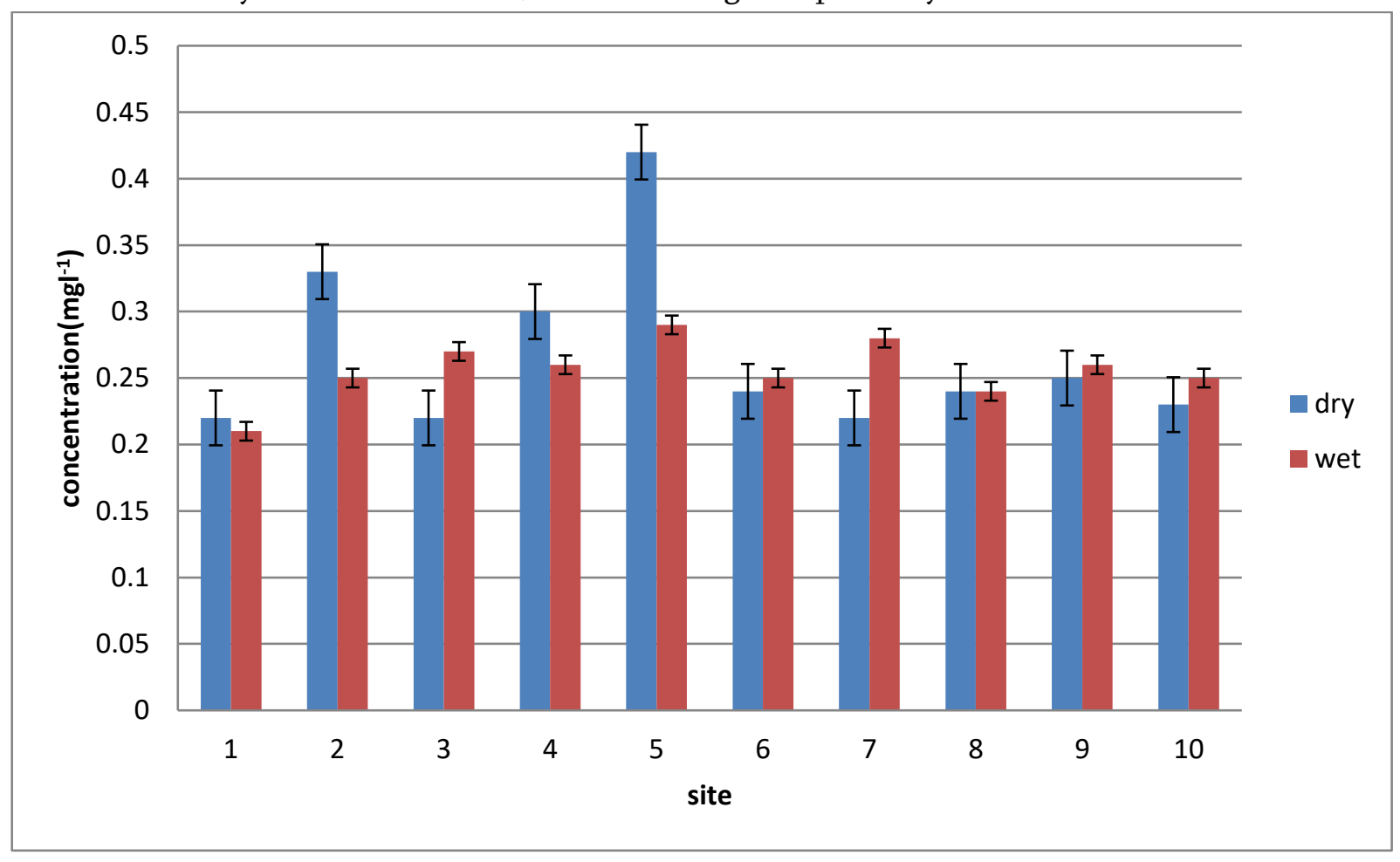

Figure 4: Lead levels in ten borehole water samples

The lead levels were higher in Site 5 in dry and wet seasons (Figure 4). Site 5 is a borehole along the chief's camp, densely populated (Table 1), the septic tanks mean distance was at about $16.2 \mathrm{~m}$, in this densely populated site there was no elaborate waste disposal as well as waste management practices in the area. The septic tank waste disposal was not entirely effective, the waste may leak and contaminate groundwater. The lead-in water samples were in the minimum range of $0.220 \pm 0.010 \mathrm{mgl}^{-1}$ to a maximum of $0.42 \pm 0.01 \mathrm{mgl}^{-1}$ during the dry and with a minimum range of $0.28 \pm 0.02$ to a maximum of $0.29 \pm 0.01 \mathrm{mgl}^{-1}$ in the wet seasons (Table 4.3). However the baseline data for lead values were not available for comparison, but the availability of lead in water, shows that it is likely that human activity has had an accumulative effect to reach this level probably as a result of disposal of lead ions from human activity e.g. fecal matter containing trace levels of lead over time. [8] [20] in his study suggested that the use of leaded petrol in cars, generators and even some mechanic workshops especially battery charging at the chiefs camp could contribute to contamination of borehole water by lead. In the study, the distance of septic tanks on levels of lead, had little significance. Great attention should be paid to levels of lead, it has been found that lead is carcinogenic [20].

Site 10 at a mean septic tank distance of $146 \mathrm{~m}$ had the lowest levels of $\mathrm{Hg}$ in both the dry and wet seasons (Figure 5). Mercury levels were at $0.0002 \pm 0.0001 \mathrm{mgl}^{-1}$ and $0.0004 \pm 0.0001 \mathrm{mgl}^{-1}$ in dry and wet seasons respectively (Table 4). Sites 4 and 9 at close mean distances of $31.4 \mathrm{~m}$ and $33 \mathrm{~m}$ respectively had the highest levels of $\mathrm{Hg}$ at $0.0019 \pm 0.0001 \mathrm{mgl}^{-1}$ during the dry and wet seasons respectively, which were slightly above the 
KEBS recommended levels of $0.001 \mathrm{mgl}^{-1}$ but were within WHO levels of $0.006 \mathrm{mgl}^{-11}$ (Table 4). It was observed that boreholes that were closer to the septic tanks had higher levels of mercury in both dry and wet seasons. These levels were within recommended value by WHO of $0.006 \mathrm{mgl}^{-1}$ (Table 4).

Mercury was present in all water samples analyzed (Figure 5). Site 4 at Mbathi's house with a borehole which has been in use for 15 years had the highest level in dry season. The homestead is at a higher side of property's slope and septic tank mean distance of $31 \mathrm{~m}$. Site 9 is at Albanus apartments, borehole next to a flat of 60 houses there is one big capacity septic tank at about $32 \mathrm{~m}$ (Table 2), mercury from cosmetics products from wastewater and feces from Mbathi's and 60 houses deposited in septic tank contaminate water from the boreholes at level slightly higher than KEBS but within WHO recommended (Table 4). . In the study, the distance of septic tanks on levels of lead, had little significance. These levels of mercury cannot be overlooked due to its effects on the kidney, central nervous system and physically deformed babies [4].

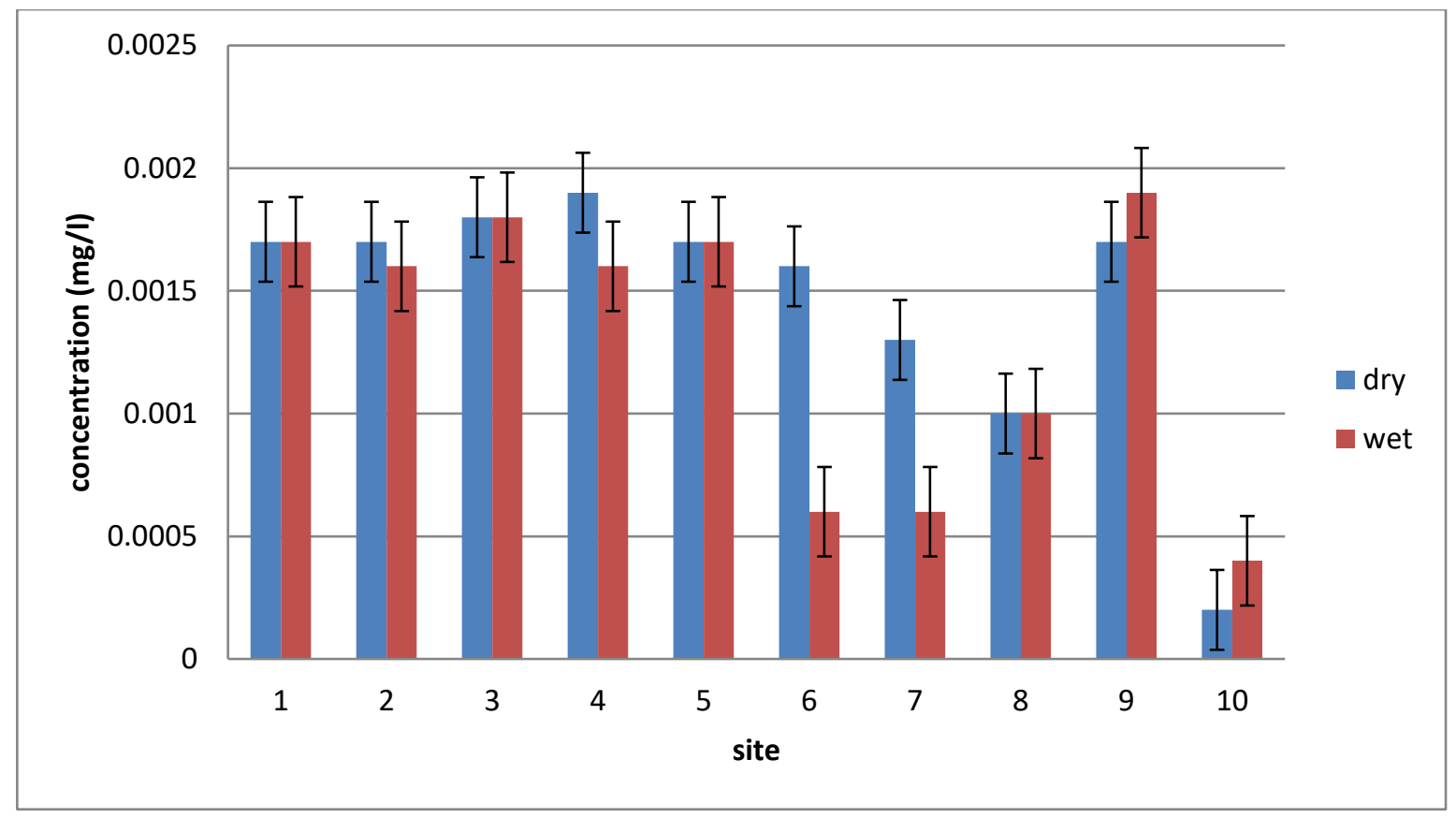

Figure 5: Mercury levels in ten borehole water samples

The highest levels of Manganese (Mn) were in site 5 at $16.2 \mathrm{~m}$ (Table 2) in both dry and wet seasons, at 0.26 $\pm 0.0012 \mathrm{mgl}^{-1}$ (Table 4). Site 10 at a mean distance of $146 \mathrm{~m}$ recorded the least levels in both dry and wet seasons (Figure 6). It was observed that Sites 5 at nearby mean septic tanks distance of $16.2 \mathrm{~m}$ had higher levels of manganese as compared to the ones far way in dry season. Also, Mn levels were higher in all sites as compared to the levels recommended by WHO and KEBS of $0.01 \mathrm{mgl}^{-1}$.

Manganese levels were generally higher in all the samples (Table 2) than the recommended levels of $0.01 \mathrm{mgl}^{-1}$ by WHO, KEBS and NEMA in drinking water (Table 2). Site 10 is Ndungu Ole Kapara borehole in a remote area with low population that may not contaminate the water. This could be attributed to high presence of manganese in rocks or soil in the area. Site 5 borehole is at the chief's camp in a densely populated area that can cause water contamination. Site 7 is a Muslim mosque and a slaughterhouse nearby in a densely populated area (Table 1) that may cause water contamination. According to [21] slaughterhouses are a significant source of water pollution and some of impacts include: release of highly polluted effluent containing blood and feacal 
matter which may find its way to water sources. Densely populated areas suffer from strain on available amenities that includes waste disposal systems and water [13]. Some of health effects caused by Manganese include; hallucinations, Forgetfulness, nerve damage, Parkinson disease, Lung embolism and bronchitis [4].

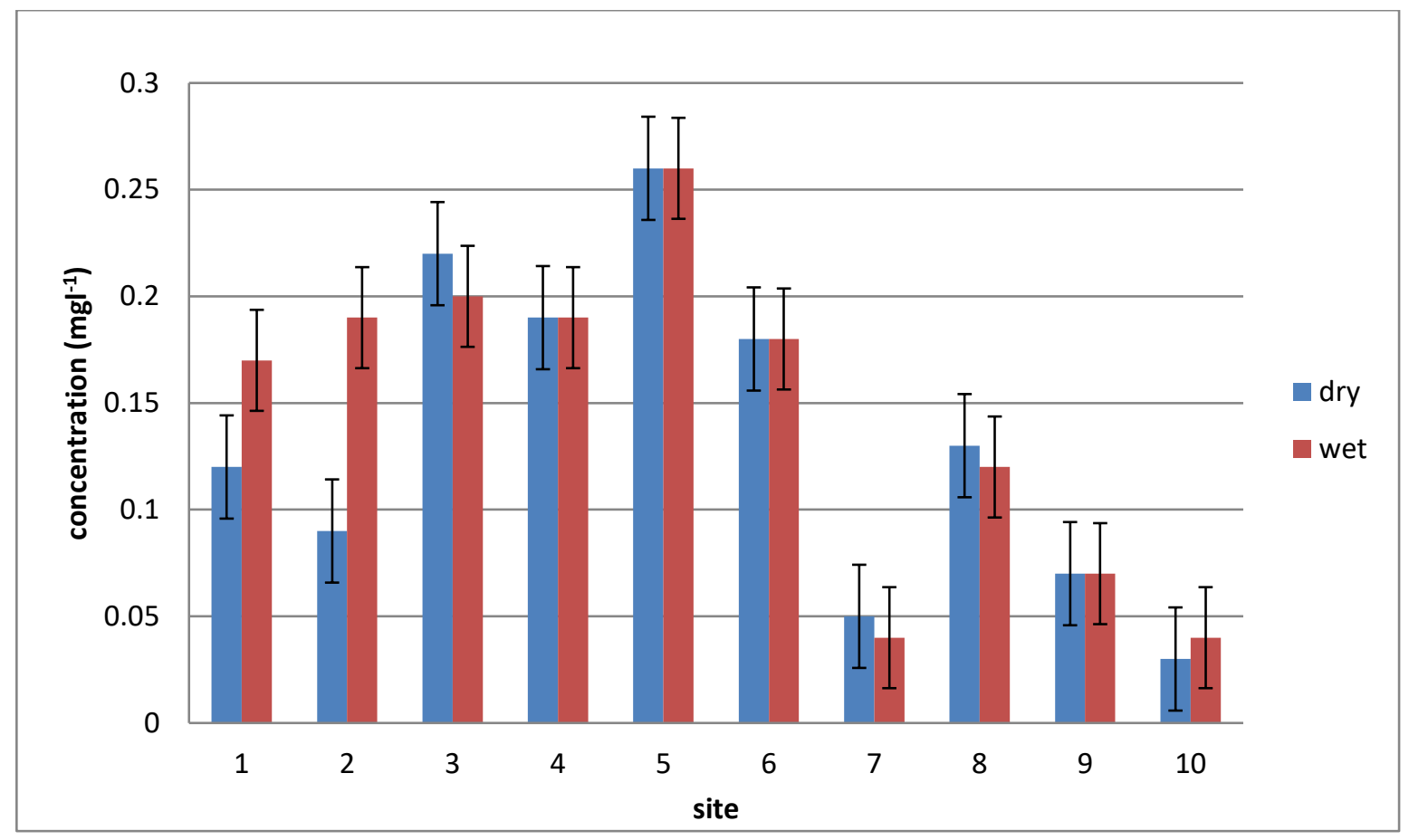

Figure 6: Manganese levels in water samples

The quantities of cadmium (Cd) and chromium (Cr) were below detectable limits of $0.001 \mathrm{mgl}^{-1}$ and $0.005 \mathrm{mgl}^{-1}$ irrespective in boreholes water from the septic tanks in all the sites during both dry and wet season (Table 4). Cadmium and chromium were found to below detectable limits, could be due to minimum human activities that raise the levels e.g., agrochemicals, some fertilizers containing $\mathrm{Cd}$ as impurities, especially phosphate fertilizers in fecal matter containing phosphate from consumed food had no influence on $\mathrm{Cd}$ and $\mathrm{Cr}$ residue levels in water. The poisonous species, hexavalent chromium, is highly soluble and easily moves within the environment [22] was not observed; which was not evident in the area at the time of the study. The water samples are free from $\mathrm{Cd}$ and $\mathrm{Cr}$ contamination therefore safe for human consumption as they were below the recommended values by WHO and KEBS of $0.003 \mathrm{mgl}^{-1}$ and $0.005 \mathrm{mgl}^{-1}$ for Cd while Cr at $0.05 \mathrm{mgl}^{-1}$ for all the two bodies respectively (Table 4). Cadmium and hexavalent form of chromium has been found to be carcinogenic [23] and [24]. Cadmium was found to cause anemia and even hepatic disorders [22].

High concentrations of some of the metals observed in the wet season samples could be an indication that the soluble forms of the metals are either present in the environment or produced after chemical reaction have occurred this is consistent to a study done by [25]. This study concurs with [26] that there is a need to educate property owners on the importance of groundwater protection and also regular borehole water quality monitoring because the residents depend on the same boreholes for domestic water uses. 


\section{IV.CONCLUSIONS}

The proximity of the boreholes to the mean septic tanks distance had a significant effect on the levels of lead, mercury and manganese but had no effects on the levels of zinc, cadmium and chromium in the borehole water samples. Boreholes closer to the septic tanks showed higher levels of heavy metal as compared to the ones far away but these levels were below the recommended values by WHO and KEBS. It was also observed that human activities had a huge influence on the quality of water for instance Site 5 was in a densely populated area and had four septic tanks within the $15 \mathrm{~m}$ radius had high levels of heavy metals.

Manganese levels were generally higher in all the samples than the recommended levels of $0.01 \mathrm{mgl}^{-1}$ and $0.03 \mathrm{mgl}^{-1}$ by WHO and KEBS in drinking water respectively except Site 10 where the value was within the recommended level of $0.03 \mathrm{mgl}^{-1}$ of KEBS limits of manganese in the dry season. The cadmium and chromium levels were below detectable limits (BDL) in both the seasons for all the borehole water samples analyzed, do not cause any health threat to human and environment

The results showed there was stronger relationship between the distance of borehole from septic tanks and some heavy metal levels e.g. Lead, mercury and Manganese.

\section{RECOMMENDATIONS}

Regular analysis of the heavy metals in borehole water to be conducted due to their accumulation nature with time.

WARMA to document the number of boreholes in the area and to provide guidelines on setting up new ones.

The source of highly toxic metals like lead, and mercury in water be investigated further. Pesticide residues levels should be investigated in borehole water samples

\section{ACKNOWLEDGEMENT}

We are grateful to Cropnut Laboratories which provided the instruments for sample analysis

\section{REFERENCES}

[1]. Cobbina J.S., Duwiejuah B.A., Quansah R., Obiri S., Bakobie N. (2015): Comparative Assessment of Heavy Metals in Drinking Water Sources in Two Small-Scale Mining Communities in Northern Ghana, International Journal of Environmental Research and Public Health.

[2]. Jeje J.O., Oladepo K.T. (2014): Assessment of Heavy Metals of Boreholes and Hand Dug Wells in Ife North Local Government Area of Osun State, Nigeria, International Journal of Science and Technology 3:4

[3]. Momodu A. M and Anyakora A. C. (2009): Heavy Metal Contamination of Ground Water: The Surulere Case Study, Research Journal Environmental and Earth Sciences 2:39-43.

[4]. Gautam K. R., Sharma K. Sanjay, Mahiya S, Chattopadhyaya (2014): Contamination of Heavy metals in aquatic media-Metals in Aquatic Media:Transport, Toxicity and Technologies for Remediation.

[5]. Njar, G. N.,Iwara, A.I., Offiong, R.A., Deekor, T.D., (2012): Assessment of Heavy Metal stauts of boreholes in Calabar South Local Government area, Cross River State, Nigeria, Ethiopian Journal of Environmental Studies and Management 5:1.

[6]. Idoko, O.M.(2010): Seasonal variation in iron in rural groundwater of Benue State, middle belt Nigeria. Pakistan Journal of Nutrition, 9(9): 892895 
[7]. Bortey-Sam N., Nakayama S. M. M., Akoto O., Ikenaka Y., Baidoo E., Mizukawa H., Ishizuka M. (2015): Ecological Risk of Heavy Metals and a Metalloid in Agricultural Soils in Tarkwa, Ghana, International Journal of Environmental Research and Public Health ISSN 1660-4601.

[8]. Adumanya O. C. U., Akunna T.O., Lele, K. C., Ogu, U. J. F., (2013): Assessment of heavy metals in borehole water in Umuagwo-Ohaji L.G.A, Imo Sate, International Journal of Research and Reviews in Pharmacy and Applied science, 3(3)315-320

[9]. World Health Organization (2014): Chemicals of Public Health concern and their Management in the African Region.

[10]. World Health Organization WHO (2006): Guideline for Drinking Water Quality. Vol. 2 Recommendations, World Health Organization, Geneva, pp: 130.

[11]. Adegoke, A. and Stenstrom, T. 2019. Cesspits and Soakpits. In: J.B. Rose and B. JiménezCisneros, (eds) Global Water Pathogen Project. http://www.waterpathogens.org (J.R. Mihelcic and M.E. Verbyla) (eds) Part 4 Management Of Risk from Excreta and Wastewater) http://www.waterpathogens.org/book/cesspitsandsoakpits Michigan State University, E. Lansing, MI, UNESCO.https://doi.org/10.14321/waterpathoge ns. 58

[12]. Tilley A.E., Luthi C., Morel A., Zurbrugg C., Schertenlein R., (2014): Compendium of Sanitation Systems and Technologies.

[13]. USEPA (2005): A Homeowner's Guide to Septic Systems. www.epa.gov/owm/septic

[14]. Government of Kenya (GoK) (2019): 2019 Kenya Population and Housing Census: Distribution of Population by Adminstrative units, Kenya National Bureau of Statistics.

[15]. Abong'o D.A, Onyatta J.O, Hinga M (2017) The Effect of Septic Tanks Sewage Disposal System Distances On Borehole Water Quality in
Ongata Rongai, Kajiado County, Kenya: European International Journal of Science and Technology $6: 1-10$

[16]. APHA (1998): Standard methods for the examination of water and wastewater, 20th ed. Washington, DC, American Public Health Association.

[17]. USEPA, (2004): Guidelines for Water Reuse, US Government Printing Office, Washington DC.

[18]. US EPA (United States of Environmental Protection Agency) (2002). National Recommended Water Quality Criteria. Washington DC. 25 pp.

[19]. WHO (2003): Zinc in Drinking-water, Background document for development of WHO Guidelines for Drinking-water Quality. World Health Organization, Geneva, Switzerland.

[20]. Hashim M.A., Mukhopadhyay S., Sahu N. J., Sengupta B. (2011): Remediation technologies for heavy metal contaminated groundwater,Journal of Environmental Management 92:2355-2388.

[21]. Singh L.A., Jamal S., Baba A.S., Islam M., (2014):Environmental and Health Impacts from Slaughter Houses Located on the City Outskirts: A Case Study. Journal of Environmental Protection, 5, 566-575.

[22]. Khopkar, S.M. (2006): Environmental Pollution, Monitoring and Control, New Age.

[23]. Elinge C. M., Itodo A. U., Peni I. J., BirniniYauri U. A., Mbongo A. N. (2011): Assessment of heavy metals concentrations in bore-hole waters in Aliero Community of Kebbi Estate, Advances in Applied Science Research 2:4 279282

[24]. Al -Saleh, I. and Al- Doush, I. (1998): "Survey of trace elements in household and bottled drinking water samples collected in Riyadh, Saudi Arabia". The Science of the Total Environment, 216:181 -192 
[25]. Elkins, H.B. and Pagnotto, L.D. (1980). Industrial Health Hazards in Treatise of Environment, 218: 185-201.

[26]. Eze C.L., Eze E. M., (2015): Investigation of Possible Groundwater Contamination from Septic System Siting in Port Harcourt, Nigeria. Journal of Natural Sciences Research 5:10, 83-

88 .

\section{Cite this article as :}

N. K. Ochiba, D. A. Abong'o, J.O. Onyatta, "The Assessment of The Effect of Proximity of Septic Tanks on The Levels of Selected Heavy Metals in Borehole Water from Ongata Rongai, Kajiado County, Kenya", International Journal of Scientific Research in Science, Engineering and Technology (IJSRSET), Online ISSN : 2394-4099, Print ISSN : 2395-1990, Volume 8 Issue 4, pp. 64-76, July-August 2021. Available at doi : https://doi.org/10.32628/IJSRSET218424

Journal URL : https://ijsrset.com/IJSRSET218424 